\title{
Neoliberal order and the collapse of a mixed economy
}

\section{Hann, Chris (2019) Repatriating Polányi: Market Saciety in the Visegrád States. Budapest and New York: CEU Press. 380 pages.}

Chris Hann has published a very important book containing writings related to the dramatic social change of the late 1980s and 1990s in Eastern Europe that has had very serious repercussions until now. This selection of pieces of writing fits very well into his long-term work - a huge series of anthologies and articles about the market and society, ownership, moral economy and peasantry - that focuses on Polányi and provides key perspectives for scholars and students of anthropology and sociology who are working on some of the most important economic and social institutions (see, among others, Hann, 2010; Hart and Hann, 2009; Hann and Hart, 2011; Hann, 2006).

Also, there has been a series of excellent publications in the last two years (and many more before) that have focused on reinterpreting and rethinking the works of Karl Polányi from various perspectives. These books include not only brief summaries of topics such as the state, class, money, commodification, international political economy, etc., but also certain ideas about how to apply Polányi's thoughts to the analysis of current affairs (Dale et al., 2019). Actually, Dale is over a huge series of books related to the works of Polányi that have been published during the last ten years, including his biography and various reconstructions of his works (among others, Dale, 2010; 2016a; 2016b; 2016c). The Polányian tide also contains The Moral Economists: R. H. Tawney, Karl Polányi, E. P. Thompson, and the Critique of Capitalism by Tim Rogan (Rogan, 2017), which not only contributes to the ongoing debate about the moral economy but also reinterprets new/old angles of the critique of capitalism, but not from the point of view of material inequality that is so persistent today. And this list can be continued with unavoidable, pieces such as those by Block and Sommers, although even if we include these we surely still miss very important pieces of writing (Block and Sommers, 2016).

In this most welcome Polányian wave of the last decade, this book of Hann's is exceptional and should be a basis for very important discussions thirty years after East European societies were exposed to a new cycle of market utopias. Hann 'repatriates' Polányi not only through an extremely insightful anthropological study of contemporary Hungarian and Polish society (thus not simply a discussion about Polányi and a critique of capitalism), but also brings Polányi back through rethinking socialist systems, which turn has been much awaited after thirty years of neoliberal order. 
It is important to note here that in certain ways there is no need to repatriate Polányi, as he has always been here. I will never forget the excited discussions we had as students in the early 1980s after reading Polányi at Pécs University, where the later head of the Hungarian Statistical Office, Tamás Mellár, and most importantly, the brilliant economic historian Tibor Tóth (who in a very Polányian way wrote a lot about the complementarity of large-scale landed estates and peasant farms in eighteenth- and nineteenth-century Hungarian rural history) dropped in the ideas of Polányi (and Malinowski and Thurnwald) again and again during lectures and seminars that were clouded by cigarette or cigar smoke. Furthermore, Mihály Sárkány (the first to understand Polányi's significance for Hungarian and non-Hungarian ethnography) not only translated him, but like Hann used his work in analysis as early as the 1970s. It was the former who translated Dahomey and the Slave Trade in 1972, it was he who wrote the first entry on Polányi in the Hungarian Ethnographic Encyclopedia in 1981, and continued to reflect on Polányi's work throughout his career (Sárkány, 1981; 1990). Or, like Iván Szelényi and George Konrád in their book The Intellectuals on the Road to Class Power, who argued when trying to understand the social structure of socialist Eastern Europe that in seeking the place of intellectuals in the social structure, we set out not for the category of mode of production, but from Polányi's models of economic integration' (Szelényi and Konrád, 1979: 47). Later, in the late 1980s, the 'third way' advocate Erzsébet Szalai also related the socialist economy to the idea of redistribution as understood by Polányi (Szalai, 1989; 2014). After the change of the regime, Polányi became even more popular and, for instance, József Böröcz started talking about 'simulating great transformation,' stressing longer-term continuity and the role of informality during the restructuring of the property system in Hungary immediately after the political collapse of the socialist regime (Böröcz, 1993). György Lengyel was also a great proponent of Polányian ideas as early as the 1980s (together with Zoltán Szántó), while Polányi was a key part of the economic sociology textbook at the Karl Marx University of Economics). Lengyel also published a book entitled Small Transformation that analyzed institutional change in Hungary using some of the ideas of Polányi. The list can be continued with excellent economic sociologists such as Endre Sík, Erzsébet Czakó (using the analytical perspectives of Polányi on informal 'market places') and many other people until the early 2000s when Polányi's book The Great Transformation was published due to a push by László Andor, later to become EU Commissioner for Employment, Social Affairs and Inclusion (note what a perfect Polányian portfolio he had!). Nevertheless, the EU is not a state to counterbalance the excesses of the free market, as so nicely pointed out by Maria Markantonatou and Gareth Dale in their analysis of the understanding of the state by Polányi (Dale et al., 2019). So, in this sense Polányi is not a 'return migrant' in Hungarian intellectual history, and he was more than a passing issue for historians of ideas such as János Gyurgyák and Erzsébet Vezér, who made important contributions in this respect (Gyurgyák, 1986; Vezér, 1986). We can even say that Polányi has been one the most consensual thinkers to be used to explain the real or imagined specialities of East European and Hungarian economic and institutional change. Even more, he survived well the change of the regime, which unfortunately threw out so 
many key figures from mainstream Hungarian scholarly discussions (the socialist economists, from Varga to Kalecki, and super-important Marxist thinkers as Lukács).

But he has not been here in some other ways, which gap Hann sees with very clear eyes, and feels with great sensitivity. Chris Hann in this book claims that the deeper cause of Brexit is not migration from the Visegrád countries but the institutions of a global neoliberal order' (p. 321). Even more, he argues, this relationship between the neoliberal order and the rise of nationalism is not only valid in the case of Britain, but in Eastern Europe as well. We should see historical changes such as the rise of authoritarian nationalism as a dual movement against market utopia, especially when we concentrate on the very concrete social arrangements in the Polish and Hungarian countryside that have been put under dramatic stress by the neoliberal turn (p. 321; Polányi, 1986; 2004). This perspective is very much in line with the views of Polányi himself, as in 1945 he also argued that the introduction of a free market would lead to 'crazy nationalisms' in Eastern Europe:

If the Atlantic Charter really committed us to restore free markets where they have disappeared, we might thereby be opening the door to the reintroduction of a crazy nationalism into regions from which it has disappeared. (Polányi 2018a)

But the key question remains what exact mechanisms of social change led to the rise of 'crazy nationalisms,' as Polányi himself gives just a general blueprint. And it is exactly with this question that Hann repatriates Polányi with his nuanced, careful observations and a unique perspective. The trick is that, with rare eloquence and integrity, Chris Hann has formulated a coherent (non-Eurocentric, plebeian, and Polányian) intellectual and moral-political perspective with which to view the consolidation of the neoliberal era in Central and Eastern Europe. While confirming Polányi's classic argument of the 'countermovement,' Hann urges avoidance of the all too easy political and moral contempt expressed by local and global elite groups for the masses that have been pushed into a new dystopia.

From this perspective there is one very important point at which we need to start thinking together with Hann (and the people he studied in Tázlár and in the Lemko region in Southeast Poland). This is the understanding and the analysis of the socialist system, especially the late socialist system, as a mixed non-capitalist system and mixed economy that served the sociability and material needs of local people rather well. Hann again and again comes back to observations such as that presented in the following quote, in which he is surely supported by historians like Tibor Valuch who documented the development of that time (Valuch, 2001):

I have always viewed this type of cooperative as an exemplar of pragmatic market socialism, epitomizing the willingness of Hungarian policymakers to modify standard models of central planning in the interests of economic efficiency, for the benefit of the whole of society and of rural petty commodity producers in particular. Certainly this very flexible framework allowed villagers 
in places such as Tázlár, through their own hard work, to achieve high levels of material prosperity in the last decades of socialism. Unfavorable comparisons with the neighboring village of Soltvadkert, where socialist entrepreneurs were even more conspicuous, led many members to view the Tázlár cooperative as a socialist imposition and a hindrance to private farmers, even by those who benefited from its services. The 'symbiosis' of private and collective can be understood in Malinowskian terms as 'functional integration.' (p. 79)

So, there was a very flexible system combining private and collective economies and ownership, in which symbiosis satisfied the conditions of 'functional integration.' This meant stability and opportunity. It led to sophisticated forms of sociability. These observations have not been fitted into ideas about socialism, which is most often portrayed as being a homogeneous system in some way. Various authors, often using very good but partial observations, have come up with ideas like state capitalism, the redistributive state economy, state-socialism with a property vacuum, or some form of totalitarian control or fully fledged socialism that surpasses any existing form of capitalist system in terms of development. Hann warns us wisely that the situation is far more complicated, especially on a micro level.

A couple of pages later, Hann comes back with a strong critique of the Douglass North-type analysis that a functioning market economy needs a precise specification of property rights in order to function well and reduce transaction costs (namely, the price of using the market, such as the costs of contracting, etc.) (North, 1990). This institutionalist approach would of course put socialism into a 'backward category' (due to very high transaction costs). But Hann argues in the following way:

However, it is very doubtful whether new property relations will be conducive to improving the economic performance of Hungarian agriculture. Collectivization, the forcible destruction of the old property rights system in the countryside, was followed not by rigid adherence to socialist property rights conceptions but by pragmatism and the general downgrading of rights over land as all citizens were forced to embrace an entirely new constellation of property rights. This led eventually not only to a rather successful expansion of production but also to considerable socioeconomic progress, which recent attempts to restore the predominance of private property rights may jeopardize. (p. 97)

Without this point that concerns the collapse of a mixed and balanced economy and the downgrading of the idea of private property involving land, and ideological pragmatism, Hann's critique of the neoliberal order and the subsequent rise of nationalism would not stand. His view of 'pragmatic' socialism is needed to evaluate social change from the perspective of a non-capitalist Polányian system of socialism. As he points out rightly in the introduction to the book, it certainly lacked freedom and democracy in many respects, which made it vulnerable to the attacks of the market utopias which prevailed and caused huge destruction. This new, neoliberal era disrupted many of the local social arrangements that protected the everyday life of 
producers and employees in the countryside, the devastation of which led to a 'jingoist,' authoritarian dual movement and an era of 'crazy nationalism' under the premiership of Viktor Orbán.

In some ways, and I think Hann tacitly teaches us in this respect, this book moves away from the standard critiques of a neoliberal regime and points toward a more general problem. Namely, Hann is working on how Polányi and anthropology can be used to analyze mixed capitalist and, very importantly, non-capitalist systems e.g. the socialist experiment in Eastern Europe, which has been rarely understood (praised or rejected) on such grounds.

As we can see above, when Hungarian sociologists and economic sociologists wrote about socialism in Polányian terms they mainly picked up on redistribution or (in village/community studies) reciprocity (kaláka, etc) as a key form of integration, and largely ignored the ways in which various forms were integrated and/or balanced. This ignorance of scholarship in work on Eastern Europe actually goes against the original intentions of Karl Polányi, who argued that in all historical types of economy, the market and centralized redistributive bureaucracy, household and reciprocity coexisted and were linked to each other. In this context he praised, for instance, the ancient economy of the Roman Empire which was able to balance redistribution and the market in certain periods (Polányi, 1984: ch. 10). So it seems likely that he would have come to similar conclusions if he could have seen the developments, for instance, in the Hungarian or even the Polish countryside where redistribution, market, and household clearly coexisted symbiotically. Actually, the lack of success in Poland in integrating peasant households and so-called 'socialist' agriculture shows that such mixtures could be mismanaged. This mismanagement could be due to some 'minor' mistakes - for instance, setting too low prices for the products of peasants which the state bought (on small producers and farmers see the very interesting anthropological reflections in this book at p. 100), which trap was avoided by Hungarian policy makers (Nove, 1991: 136). The results of such progressive developments just have to be acknowledged, as we can see again and again in this and previous books of Hann.

The lack of attention is all the more surprising as the issue of mixed ownership and mixed economy by sector was the key innovation in the early history of Soviet socialism. Lenin could see early on that the victory of socialist ownership could not be guaranteed without building up a new economic plan that allowed for the coexistence of various forms of private and socialist economics. The new state needed Western technology and industrial culture: a mixed economy based on competition between sectors. Social and communal ownership was to be fostered and the market was to be managed by the state in a 'special' and 'contradictory' way (Krausz, 2015: 311-325). This was an imbalanced system, as we could learn from the debates between Chayanov, Bukharin, and Preobrazhensky, who thought about whether there could be an original accumulation based on the market activities of better-off peasants. This imbalance, and the consequent market shortages due to peasants' economic rationality and overly high wages for industrial workers, formed the basis for the Stalinist counter-revolution and forced industrialization, the era of which, based on the geopolitical defence rationality of one-state socialism, led to the killing of those thinkers who could have answered the above questions. Actually, Alec Nove, who 
wrote one of the best economic histories of the Soviet Union (also focusing on the above-described debates), arrived at a similar conclusion when first in 1983 he wrote that feasible socialism could exist only in the form of a mixed economy (Nove, 1991). According to him, the market was always necessary in many sectors of the economy, but there was also a need for severe control. There were sectors and segments where central control was and should be necessary, while there could also be competitive smaller state enterprises under self-management. Market-oriented cooperatives would also have had an important role and would have owned their own enterprises (like in Hungary), while smaller scale fully fledged private enterprises and competitive individuals would have also been needed. These systems would have corrected and balanced planning, which (especially if dominant) also had immanent problems: namely, investment cycles, and planning difficulties. Of course, we should stress that the lack of dominance of one sector over the other depends on very important structural conditions such as control over capital, financial, and land markets. Otherwise, while seeking to extend accumulation, the market can unstoppably eat up other sectors such as the peasantry, as already pointed out by Rosa Luxemburg (1951).

So, there were not only various types of socialisms - East German (holding-type control), Yugoslav, (self-management) Hungarian (socialist market) and Soviet, Cuban (more centralized control), etc. -but within socialisms there was variety too, which in itself could be seen as a case of tertium datur as, for instance, Szalai puts it (Szalai, 2014). I think it was no tertium, but actually the development of socialism which historically had to experiment and come to new arrangements in order to achieve 'integrated' functioning; a fact which Hann draws attention to. So, the former needed permanent reform, not opening toward a 'real' and 'fully fledged' market economy, as János Kornai, the renowned Hungarian economist of socialism and, for instance, János Fekete, at that time head of the Hungarian National Bank (and foreign banks and the IMF, then lending to Hungary and Poland) would have demanded. We can only wonder why the reform economists in Hungary, Poland and Czechoslovakia (László Antal, Tamás Bauer, Ota Sik, Attila Chikán, Károly Attila Soós, Balcerowicz, etc. - see for many of them János Mátyás Kovács, 2009, and also the recollection of ideational development by Szalai, 2014) rarely came up with ideas about how to balance the various economic logics instead of saying and repeating all the time that the state 'unfortunately' slowed down market development, or did not allow the full operation of the market. With rare exceptions (like Pál Juhász, who had partial insight into this problem of coexistence) the above-mentioned intellectuals/economists, who had on their desks some of the best empirical materials on the functioning of the socialist economy, 'in reality' could not come up with equilibrium models for what Hann observes, for instance, in his villages as societal development. So most probably before we start work on various types of symbiosis and links that include redistributive state-market-household-cooperative-urban-rural axes (meaning complex embeddedness) we need to ask again the same question that Kari Polányi-Levitt put to us at our last huge Polányi conference in May 2019: Why has Central Europe been the birthplace of market fundamentalism from Mises and Hayek until now? We have some answers from people like Bockman and Böröcz, but we need to continue the work asking which concrete mechanisms and mixed models should have been 
analyzed instead (Bockman, 2011; Böröcz, 1999). So, this is the way that we need to repatriate Polányi, and for this intellectual push it is not only critical scholars but also the inhabitants of places like Tázlár and Kiskunhalas that owe Chris Hann a lot.

ATTILA MELEGH (melegh国demagrafia.hu)

Hungarian Demagraphic Research Institute;

Corvinus University, Budapes 0074

\section{References}

Block, F. and Sommers, M. R. (2016) The Power of Market Fundamentalism: Karl Polanyi’s Critique. Cambridge, MA: Harvard University Press.

Bockman, J. (2011) Markets in the Name of Socialism: The Left-Wing Origins of Neoliberalism. Stanford, CA: Stanford University Press.

Böröcz, J. (1993) Simulating the Great Transformation: Property change under prolonged informality in Hungary. European Journal of Sociology / Archives européennes de sociologie, 34(1): 81-107.

https://doi.org/10.1017/S0003975600006561

Böröcz, J. (1999) Reaction as progress: Economists as intellectuals. In Bozóki, A. (ed.) Intellectuals and Politics in Central Europe. Budapest: Central European University Press. 245-262.

Dale, G. (2010) Karl Polányi: The Limits of the Market. Cambridge: Polity Press.

Dale, G. (2016a) Reconstructing Karl Polányi: Excavation and Critique. London: Pluto Press.

Dale, G. (2016b) Karl Polányi: A Life on the Left. New York: Columbia University Press.

Dale, G. (ed.) (2016c) Karl Polányi: The Hungarian Writings. Manchester: Manchester University Press.

Dale, G., Holmes, C. and Markantonatou, M. (eds.) (2019) Karl Polányi’s Political and Economic Thought: A Critical Guide. Newcastle: Agenda Publishing.

Gyurgyák, J. (ed.) (1986) Polányi Károly. Magyar szociológiatörténeti füzetek, 2. Budapest: Fővárosi Szabó Ervin Könyvtár.

Hann, C. (2010). Moral economy. In Hart, K., Laville, J.-L. and Cattani, A. D. (eds.) The Human Economy: A Citizen's Guide. Cambridge: Polity Press. 187-198.

Hart, K. and Hann, C. (2009) Introduction: Learning from Polányi 1. In Hart, K. and Hann, C. (eds.) Market and Society: The Great Transformation Today. Cambridge: Cambridge University Press. 1-16. 
Hann, C. Hart, K. (2011) Economic Anthropology: History, Ethnography, Critique. Cambridge: Polity Press.

Hann, C (2006) 'Not the Horse We Wanted!': Postsocialism, Neoliberalism, and Eurasia. Münster: LIT.

Kovács, J. M. (2009) Taste of the Goulash: Understanding the Hungarian 'variety of capitalism’. Tr@nsit Online. http://www.iwm.at/read-listen-watch/transitonline/taste-of-the-goulash/

Krausz, T. (2015) Reconstructing Lenin: An Intellectual Biography. New York: Monthly Review Press.

North, D. C. (1990) Institutions, Institutional Change and Economic Performance. Cambridge: Cambridge University Press

Nove, A. (1991) Economics of Feasible Socialism Revisited. London: Harper and Collins.

Luxemburg, R. (1951) The Accumulation of Capital. London: Routledge and Kegan Paul.

Polányi, K. (1972) Dahomey és a rabszolgakereskedelem. Egy archaikus gazdaság elemzése (Dahomey and the Slave Trade: An Analysis of an Archaic Economy). Budapest: Közgazdasági és Jogi Könyvkiadó.

Polányi, K. (2018) Universal capitalism or regional planning? In Economy and Society, ed. by Cangiani, M. and Thomasberger, C. Cambridge: Polity Press. 231-240.

Polányi, K. (1984) Kereskedelem, piacok és pénz az ókori Görögországban (Trade, Markets and Money in Ancient Greece). Budapest: Gondolat.

Rogan, T. (2017) The Moral Economists: R. H. Tawney, Karl Polányi, E. P. Thompson, and the Critique of Capitalism. London, Princeton University Press

Sárkány, M. (1990) Karl Polányi’s contribution to economic anthropology. In PolanyiLevitt, K. (ed.) The Life and Work of Karl Polányi: A Celebration. Montréal and New York: Black Rose Books. 183-187.

Sárkány, M. (1981) Polányi Károly. In Magyar Néprajzi Lexikon, vol. 4. Budapest: Akadémiai Kiadó. 256-257.

Szalai, E. (1989) Gazdasági mechanizmus, reformtörekvések és nagyvállalati érdekek (Economic Mechanism, Reform Attempts, and the Interests of Large Enterprises). Budapest: Közgazdasági és Jogi Könyvkiadó.

Szalai E. (2014) Autonómia vagy újkiszolgáltatottság: Tanulmányok és publicisztikai irások 2012-2014 (Autonomy or New Defenselessness: Papers and Newspaper Articles 2012-2014). Budapest: Kalligram.

Szelényi, I. and Konrád, G. (1979) The Intellectuals on the Road to Class Power. New York: Harcourt Brace Jovanovich. 
Valuch, T. (2001) Magyarország társadalomtörténete a XX. század második felében (Social History of Hungary in the Second Half of the 20th Century). Budapest: Osiris.

Vezér, E. (ed.) (1986) Írástudó nemzedékek: A Polányi család története dokumentumokban (Generations of Literates: Documents on the History of the Polányi Family). Budapest: MTA Filozófiai Intézet. 